Agron. Mesoam. 230(1):79-100. Enero-abril, 2019

ISSN 2215-3608, doi:10.15517/ma.v30i1.29671

http://www.revistas.ucr.ac.cr/index.php/agromeso

\title{
Relationship between growth traits and yield formation in Indica-type rice crop $^{1}$
}

\author{
Relación entre los rasgos de crecimiento y la formación de rendimiento en el \\ cultivo de arroz tipo Índica
}

\author{
Lázaro A. Maqueira-López ${ }^{2}$, Rogelio Morejón-Rivera ${ }^{2}$, Osmany Roján-Herrera ${ }^{2}$, Walfredo Torres-de-la-Noval ${ }^{2}$
}

1 Recibido: 6 de julio, 2017. Aceptado: 15 de enero, 2018. This work was part of the project "Yield formation in rice plants (Oryza sativa L.) and physiological variables determining it" financed by Ministerio de Educación Superior and Ministerio de Ciencia, Tecnología y Medio Ambiente, Cuba.

2 Instituto Nacional de Ciencias Agrícolas, Cuba. lalberto@inca.edu.cu (author for correspondence), rogelio@inca.edu.cu, orojan@inca.edu. cu,wtorres@inca.edu.cu

\begin{abstract}
Introduction. Climatic variation is one of the causes for the decrease in yield and its variability in Indica-type rice (Oryza sativa L.). This evidences the necessity of the study of the interaction of meteorological variables with the behavior of rice cultivars, to establish the base of management of the harvest and increase of the yield. Objective. The objective of the present study was to relate the yield of rice with variables of plant growth. Materials and methods. Four rice cultivars were planted in the "dry" season of December 2004, February 2005 and January 2006, and in the rainy season of March 2006, April 2008 and 2009, in Los Palacios, Pinar del Río province, Cuba. The yield and its components, the dynamics of plant growth (LAI and dry matter), the variation of the dry matter of the internodes, peduncle, flag leaf, leaf and leaf sheath during the grain filling phase were evaluated the panicle growth in addition to the meteorological data. A multivariate analysis was used to relate the performance to the characteristics of the plants evaluated. Results. The yield was higher in the "dry" season and to obtain higher yields, the growth dynamics of the plant and the variation of the dry matter of the third internode during the grain filling were important. In both seasons, different source-sink relationships were established and these situations depended mainly on the temperature regime at which the plants were subjected. Conclusion. Breeders, in order to increase potencial yields, may fows their atttention in grow traits during vegetative stages.
\end{abstract}

Keywords: internodes, dry matter, seed filling, starchy crops.

\section{Resumen}

Introducción. La variación climática es una de las causas para la disminución del rendimiento y su variabilidad en arroz de tipo Índica (Oryza sativa L.). Esto evidencia la necesidad del estudio de la interacción de variables meteorológicas con el comportamiento de cultivares de arroz, para establecer la base de manejo de la cosecha e incremento del rendimiento. Objetivo. El objetivo del presente estudio fue relacionar el rendimiento de arroz con variables del crecimiento de la planta. Materiales y métodos. Cuatro cultivares de arroz se sembraron en la estación "seca" de diciembre de 2004, febrero de 2005 y enero de 2006, y en la estación lluviosa de marzo de 2006, abril de 2008 y 2009, en Los Palacios, provincia Pinar del Río, Cuba. Se evaluó el rendimiento y sus componentes, la dinámica 
de crecimiento de planta (LAI y materia seca), la variación de la materia seca de los entrenudos, pedúnculo, hoja bandera, lámina y vaina de las hojas durante la fase de llenado del grano, el crecimiento de la panícula además de los datos meteorológicos. Se utilizó un análisis multivariado para relacionar el rendimiento con las características de las plantas evaluadas. Resultados. El rendimiento fue mayor en la estación "seca" y para obtener mayores rendimientos fue importante la dinámica de crecimiento de la planta y la variación de la materia seca del tercer entrenudo durante el llenado del grano. En ambas épocas, se establecieron relaciones de la fuente-sumidero diferentes y estas situaciones dependieron principalmente del régimen de temperatura a que las fueron sometidas las plantas. Conclusión. Los cultivadores, con el fin de aumentar los rendimientos potenciales, pueden centrar la atención en los rasgos de crecimiento durante las etapas vegetativas.

Palabras claves: internodios, materia seca, llenado de semilla, plantas feculentas.

\section{Introduction}

Rice (Oryza sativa L.) is one of the cereals of major significance in the world and the main food resource, after wheat, for more than half of the world population (Ruiz et al., 2005; Acevedo et al., 2006; Álvarez et al., 2008; Canfalonieri et al., 2011), mainly in developing countries. World per capita consumption is placed around the 56.9 $\mathrm{kg}(\mathrm{FAO}, 2013)$.

Climatic variation is one of the fundamental causes for yield variability of several crops, in particular on rice (Akinbile, 2013). The former statement leads to the need for the study of the interaction of meteorological variables with rice cultivar behavior to establish the basis for crop management and yield increment.

Current agriculture tends to increase the importance of genotype behavior in local environments to increase productivity. In this sense, it is fundamental knowledge of processes and mechanisms that determine growth and consequently, biological and agricultural yield, as well as how they are affected by the meteorological conditions. An important element in rice yield formation is grain filling, where fertilized ovaries develop into caryopsis (Takai et al., 2005). Its duration and filling rate are essential elements contributing to final yield. Authors that studied the grain filling process in cereals, stated that the relation among sink-source organs is crucial for the event, where grain filling (sink) could be limited by leaf photosynthetic activity (source), the grain carbohydrate deposition (sink) or both and where climate is important in cultivar response (Yang and Zhang, 2010; Hernández and Soto, 2012; 2013).

All these aspects provide information for using inputs more efficiently constitutes guidelines for breeders, with the purpose to develop cultivars more adapted and with higher yield potentials given. In particular, the thermal and radiation environment, establish a production ceiling difficult to overcome with the input increase (Tao and Zhang, 2013).

Production increase can be achieved by expansion of current crop area, higher yield per-unit area, or both (Bruisma, 2009). Furthermore, the yield increases per-unit area can be achieved through increases of yield potential (Yp) or through reductions of yield gaps (Yg) (Fischer et al., 2014). Yield potential is defined as the yield of a cultivar when grown in an environment to which is adapted, with nutrients and water non-limiting and with biotic stresses effectively controlled (Evans and Fischer, 1999). Hence, Yp is determined by solar radiation, temperature, carbon dioxide concentration, and crop physiological attributes governing light interception, conversion into biomass, and partition into harvestable organs. Yield gaps could be analyzed through well-calibrated crop simulation models coupled with high-quality weather, soil and crop management data (Merlos et al., 2015).

Improving the genetic $\mathrm{Yp}$ of tropical, irrigated rice varieties is a priority objective of rice breeding programs worldwide in the interest of achieving food security and maintaining political stability (Dingkuhn et al., 2015). But 
Yp has stagnated at about $10 \mathrm{Mg} / \mathrm{ha}$ since the Green Revolution. For this purpose, growth studies and its relation with meteorological variables are needed.

Growth models enables the simulation and evaluation of probable productive scenes, but this approach is useful for global situations and useless for local analyses when the causes of crop response are unknown. Current simulation models are deficient in genetic, physiological and edaphic parameters that explain yield. This features were informed (Iizumi et al., 2011; 2013; Tao and Zhang, 2013) and regretfully, there is a lack of integral studies with a systemic approach for the establishment of rice yield formation, taking into account the cultivar, prevailing climatic variations in a particular locality and their effect on biological and agricultural plant productivity, with the purpose to answer the causes of plant response and develop actions in order to increase productivity, through a more efficient local crop management.

The aim of the present study was to relate rice yield with plant growth traits.

\section{Materials and methods}

The study was conducted in areas of the Experimental Station "Los Palacios" of Instituto Nacional de Ciencias Agrícolas (National Institute of Agricultural Sciences) at Pinar del Río, Cuba, located at 22 $44^{\prime}$ North latitude and $83^{\circ} 45^{\prime}$ West longitude, 60 masl. Cultivar characteristics are shown in Table 1: two short growth period (INCA LP-5 and Reforma) and two medium growth period (INCA LP-2 and J-104) rice cultivars (indica type), were sowed in "dry" season (December 2004, February 2005 and January 2006) and "rainy" season (March 2006, April 2008 and 2009), in a Hydromorphic Gley Nodular Ferruginous Petroferric soil (Hernández et al., 1999), with a direct sowing technology, using a $120 \mathrm{~kg} / \mathrm{ha}$ seed rate. Crop management was conducted according to technical instruction of rice cultivation (MINAG, 2008). A random design with four replications was used, with experimental plots of $25 \mathrm{~m}^{2}$.

Table 1. Main biological characteristics of rice cultivars (Oryza sativa L.) used in the experiments developed in Los Palacios province of Pinar del Río, Cuba, during 2004 to 2009.

Cuadro 1. Características biológicas principales de cultivares de arroz (Oryza sativa L.) usados en los experimentos desarrollados en Los Palacios provincia de Pinar del Río, Cuba, durante 2004 a 2009.

\begin{tabular}{lcccc}
\hline Characteristics & \multicolumn{3}{c}{ Cultivars } \\
\cline { 2 - 5 } & INCA LP-5* & Reforma* & INCA LP-2** & Jucarito 104* \\
\hline Parents & $\mathbf{2 0 7 7 / C P 1 C 8}$ & $\begin{array}{c}\text { Taichun Senyu204 / } \\
\text { ChianungSenyu14 }\end{array}$ & IR 759-54-22/6066 & IR 480-5-2/IR 30- \\
16-1 & \\
\hline Cycle duration (days) & & & 134 & 147 \\
"Dry" season & 128 & 122 & 114 & 119 \\
"Rainy" season & 110 & 105 & "medium" & "medium" \\
Classification due to cycle & "short" & $90-110$ & 24 & 85 \\
Plant height (cm) & 90 & 26 & 90 & 23 \\
Panicle size (cm) & 23 & 150 & 29 & 112 \\
Grain number per-panicle & 90 & 26.6 & & 28 \\
One-thousand kernel weight & 29.5 & & 7.8 & 8.6 \\
Maximum attainable yield (t/ha) & & 7.5 & 6.7 & 5.9 \\
"Dry" season & 8.2 & 5.7 & & \\
"Rainy" season & 5.7 & & & \\
\hline
\end{tabular}

Data obtained from * MINAG (2005) and ** Pérez (1998) / Datos obtenidos de *MINAG (2005) y **Pérez (1998). 
Economic yield and its components were determined at each experimental plot according to Amador and Peña (1986), in two areas of $1 \mathrm{~m}^{2}$ per plot and values were expressed in t/ha at $14 \%$ of grain moisture; panicle number per square meter $\left(\mathrm{Pan} / \mathrm{m}^{2}\right)$ was evaluated counting method on a surface of $0.50 \mathrm{~m}^{2}$ with four repetitions per experimental plot; grain number per panicle (G/pan) was evaluated from twenty panicles randomly taken from each experimental plot, grains were separated, counting filled and unfilled, and weight of 1000 grains from two samples of filled grains, per experimental plot.

Plants growth dynamics were evaluated from 25 days after emergence (DAE) until harvest, at periods of nearly fifteen days, from an area of $0.25 \mathrm{~m}^{2}$ of each experimental plot, determining organ (stems, leaves, and panicles) dry weight (grams) and aerial dry weight (sum of organs), foliar surface was determined through a foliar surface integrator AM 300, and expressed per unit of ground area (LAI). Dry weights were obtained after oven drying at $70{ }^{\circ} \mathrm{C}$ during 72 hours, until constant weight.

Actual data were adjusted by means of regression analysis using the mathematical function (1), with weight as dependent variable and DAE as the independent variable. Growth analysis indexes were obtained according to Torres (1989) and García et al. (1998), such as growth rate (GR, equation 2) of dry weight and leaf area index (LAI), leaf area duration (LAD, equation 3), and net assimilation rate (NAR, equation 4), where P or A are the dry weights or LAI, respectively, and $t$ is the DAE.

$$
\begin{aligned}
& y=e^{\left(b_{o}+b_{1} x+b_{2} x^{2}\right)} \\
& G R=\frac{d P}{d t} \text { or } \frac{d A}{d t} \\
& L A D=\int_{i}^{i o} A \\
& N A R=\frac{1}{A} * \frac{d P}{d t}
\end{aligned}
$$

Different growth parameters were estimated from the first and second derived of mathematical functions attained, such as time for the total dry matter maximum (t TDM max), total dry matter maximum (TDM max), time for the total dry matter growth rate maximum (t TDM GR max), total dry matter growth rate maximum (TDM GR max), time for the leaf area index maximum ( $t$ LAI max), leaf area index maximum (LAI max), time for the leaf area index growth rate maximum (t LAI GR max), leaf area index growth rate maximum (LAI GR max), net assimilation rate at the time of the total dry matter maximum (NAR t TDM max), net assimilation rate at the time of the leaf area index growth rate maximum (NAR t LAI GR max), net assimilation rate at the time of the leaf area index maximum (NAR t LAI max), and leaf area duration (LAD).

The contribution of main stem dry weight to grain filling was evaluated, from 25 selected plants at panicle differentiation stage, on five representative plants per experimental plots for each treatment (genotype and planting date) in three different moments (anthesis, ten and twenty days after anthesis). Each stem was divided into parts: flag leaf (FL), foliar sheaths (FS), foliar blades (FB), the three upper internodes, numbered from apex to base, first, second and third internode (Int 1, Int 2 and Int 3, respectively) and peduncle (Ped), spikelet (S) and dry matters were determined.

Grain filling dynamics per treatment were established from grain dry weights obtained from ten panicles at each experimental plot, according to CIAT (1985), from anthesis to harvest, every three days. Grains were separated from rachis and their dry weight determined. 
Yield and its components were processed through variance analysis according to the experimental design employed and the range was estimated by means of the confidence interval at $95 \%$ of probability using the standard error of variance analysis. Data matrixes of yield and growth variables and attributes were processed by means of a multivariate analysis with Biplot representations and auto vectors, to determine association degree among them (Morejón et al., 2005).

\section{Results}

Sowing dates and seasons showed differences in meteorological variables and they were, in principle, responsible for plant performance. Sowing dates in "dry" season began with lower temperatures and ended with warmer, in contrast, in "rainy" season temperatures were more stable during growth, but during reproductive stage somewhat higher. As well, solar global radiation varied in an almost regular manner according to sowing dates in different years but differences were attained between "dry" and "rainy" season, in the former, radiation increased towards the end of the growing period (from 16 to $25 \mathrm{Mj} / \mathrm{m}^{2} / \mathrm{day}$ ), while in the latest, it decreased (from around 25 to $23 \mathrm{Mj} / \mathrm{m}^{2} /$ day).

\section{Yield and yield components}

Yield and its main components, for both planting seasons (Table 2), showed variation among cultivars for a specific sowing date or season, and it was difficult to establish a defined pattern for these variables, due to the interaction between meteorological conditions and cultivars. Despite the former, in "dry" season, short cycle cultivars showed a better behavior that medium cycle ones (Table 1). In general, yield and its components in "rainy" season decreased (Table 1) and short cycle cultivars did not show the superiority observed as in "dry" season.

In "rainy" season, as a mean, cultivars had fewer panicles per square meter ( $72 \mathrm{Pan} / \mathrm{m}^{2}$ less) and a longer number of unfilled grains per panicle (more than 6\%); nevertheless, total grain number per panicle showed no variation among seasons. Consistently, yields in "rainy" season decreased by more than $1.0 \mathrm{t} / \mathrm{ha}$.

Plants grew slower and more in "dry" season compared to "rainy" season, in the foliar surface as well as in dry matter accumulation. Differences in growth variables were more pronounced among sowing dates than among cultivars, for a given season.

Leaf area index (LAI) increased after emergence, achieving a maximum value and declining towards the end of the development period (Figure 1). Maximum values were in the order of 3.81 for "dry" season, and 2.55 for "rainy" season at 103 and 83 DAE, respectively, showing restrictions in the source in the raining season plantings.

Aerial dry weights in both sowing seasons followed the course of individual organs (mainly stems and leaves) with an increase until the final plant growth stages (Figure 2). Maximum values (TDM max) were attained at 145 DAE, for "dry" season, and 117 DAE, for "rainy" season, coinciding with the maturation stage, with magnitudes from 1264 and $1061 \mathrm{~g} / \mathrm{pl}$, in "rainy" and "dry" seasons, respectively. "Rainy" season was characterized by a faster and lesser development. In both seasons, maximum LAI occurred around the moment that plants attained their dry matter maximum growth rate (GR).

Multivariate analysis between yield and different growth variables showed, in "dry" season (Figure 3A) a positive relation between yield and leaf area index maximum (LAI max), leaf area duration (LAD), and time for the leaf area index growth rate maximum (t LAI GR max), and an almost negative relation with time for the total dry matter maximum (t TDM max), time for the total dry matter growth rate maximum (t TDM GR max), time for the leaf area index maximum (t LAI max), time for the leaf area index growth rate maximum (t LAI GR max). A different situation was presented for "rainy" season (Figure 3B), where yield was related positively with leaf 
Table 2. Economic yield ( $\mathrm{t} / \mathrm{ha})$ at $14 \%$ moisture of the grain and its main components of the rice cultivars (Oryza sativa L.), in different dates and seasons of planting in Los Palacios, province of Pinar del Río, Cuba (December 2004, February 2005, January 2006, March 2006, April 2008 and April 2009).

Cuadro 2. Rendimiento económico (t/ha) al 14\% de humedad del grano y sus componentes principales de los cultivares de arroz (Oryza sativa L.), en diferentes fechas y temporadas de siembra en Los Palacios, provincia de Pinar del Río, Cuba (diciembre 2004, febrero 2005, enero 2006, marzo 2006, abril 2008 y abril 2009).

\begin{tabular}{|c|c|c|}
\hline Cultivars & Full grain number per panicle & Yield (t/ha) \\
\hline \multicolumn{3}{|c|}{ December 2004} \\
\hline INCA LP-5 & $81 \pm 4.5$ & $6,2 \pm 0.2$ \\
\hline Reforma & $104 \pm 4.5$ & $6,2 \pm 0.2$ \\
\hline INCA LP-2 & $88 \pm 4.5$ & $5,5 \pm 0.2$ \\
\hline $\mathrm{J}-104$ & $97 \pm 4.5$ & $5,3 \pm 0.2$ \\
\hline SEx & $2.31 *$ & $0.12 *$ \\
\hline \multicolumn{3}{|c|}{ February 2005} \\
\hline INCA LP-5 & $80 \pm 3.3$ & $6.0 \pm 0.2$ \\
\hline Reforma & $85 \pm 3.3$ & $5.5 \pm 0.2$ \\
\hline INCA LP-2 & $87 \pm 3.3$ & $4.8 \pm 0.2$ \\
\hline $\mathrm{J}-104$ & $78 \pm 3.3$ & $5.3 \pm 0.2$ \\
\hline SEx & $1.17 *$ & $0.12 *$ \\
\hline \multicolumn{3}{|c|}{ January 2006} \\
\hline INCA LP-5 & $70 \pm 16.7$ & $6.2 \pm 0.1$ \\
\hline Reforma & $107 \pm 16.7$ & $6.1 \pm 0.1$ \\
\hline INCA LP-2 & $81 \pm 16.7$ & $5.6 \pm 0.1$ \\
\hline $\mathrm{J}-104$ & $74 \pm 16.7$ & $5.7 \pm 0.1$ \\
\hline SEx & $8.53 *$ & $0.07 *$ \\
\hline \multicolumn{3}{|c|}{ March 2006} \\
\hline INCA LP-5 & $66 \pm 1.5$ & $4.8 \pm 0.2$ \\
\hline Reforma & $70 \pm 1.5$ & $4.2 \pm 0.2$ \\
\hline INCA LP-2 & $70 \pm 1.5$ & $3.8 \pm 0.2$ \\
\hline $\mathrm{J}-104$ & $65 \pm 1.5$ & $4.6 \pm 0.2$ \\
\hline SEx & $0.75^{*}$ & $0.10 *$ \\
\hline \multicolumn{3}{|c|}{ April 2008} \\
\hline INCA LP-5 & $76 \pm 2.4$ & $4.6 \pm 0.2$ \\
\hline Reforma & $81 \pm 2.4$ & $4.2 \pm 0.2$ \\
\hline INCA LP-2 & $71 \pm 2.4$ & $3.9 \pm 0.2$ \\
\hline $\mathrm{J}-104$ & $72 \pm 2.4$ & $4.5 \pm 0.2$ \\
\hline SEx & $1.24 *$ & $0.10 *$ \\
\hline \multicolumn{3}{|c|}{ April 2009} \\
\hline INCA LP-5 & $71 \pm 2.7$ & $4.8 \pm 0.3$ \\
\hline Reforma & $84 \pm 2.7$ & $4.4 \pm 0.3$ \\
\hline INCA LP-2 & $71 \pm 2.7$ & $3.4 \pm 0.3$ \\
\hline $\mathrm{J}-104$ & $76 \pm 2.7$ & $4.2 \pm 0.3$ \\
\hline SEx & $1.40^{*}$ & $0.13 *$ \\
\hline
\end{tabular}

Confidence interval at $95 \%$ of probability taking into account the experimental error of the analysis of variance. $* \mathrm{p} \leq 0.05$, according to Duncan Multiple Range Test / Intervalo de confianza al 95\% de probabilidad teniendo en cuenta el error experimental del análisis de varianza. * p $\leq 0,05$, según dócima de Rangos Múltiples de Duncan. 

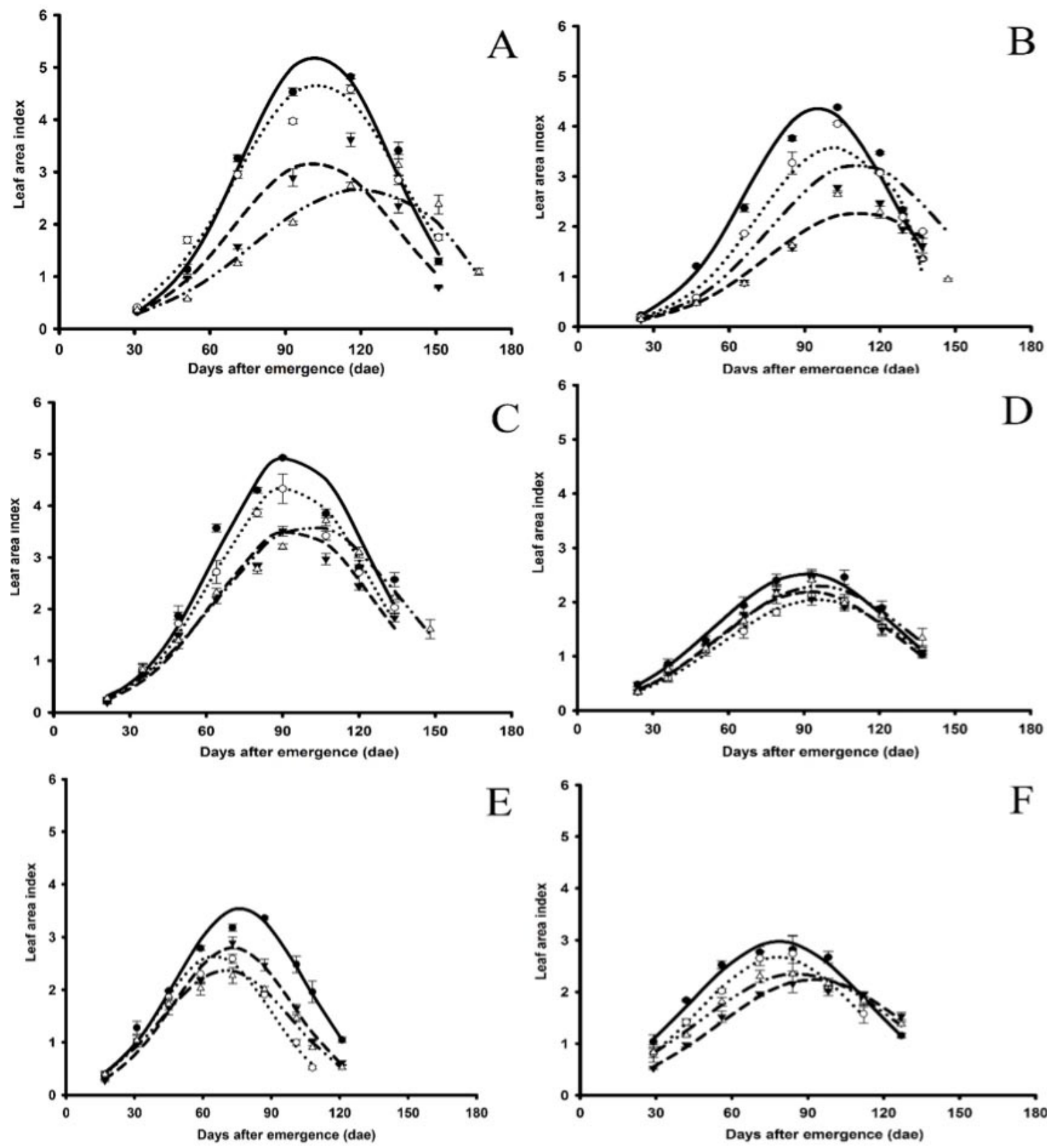

INCA LP 5

O

INCA LP $2 \Delta$

$\mathrm{J}-104$

Figure 1. Growth dynamics of the leaf area index (LAI) of rice plants after emergence in Los Palacios, province of Pinar del Río, Cuba (A December 2004, B February 2005, C January 2006, D March 2006, E April 2008 and F April 2009).

Figura 1. Dinámica de crecimiento del índice de área foliar (LAI) de las plantas de arroz después de la emergencia en Los Palacios, provincia de Pinar del Río, Cuba (A diciembre 2004, B febrero 2005, C enero 2006, D marzo 2006, E abril 2008 y F abril 2009). 

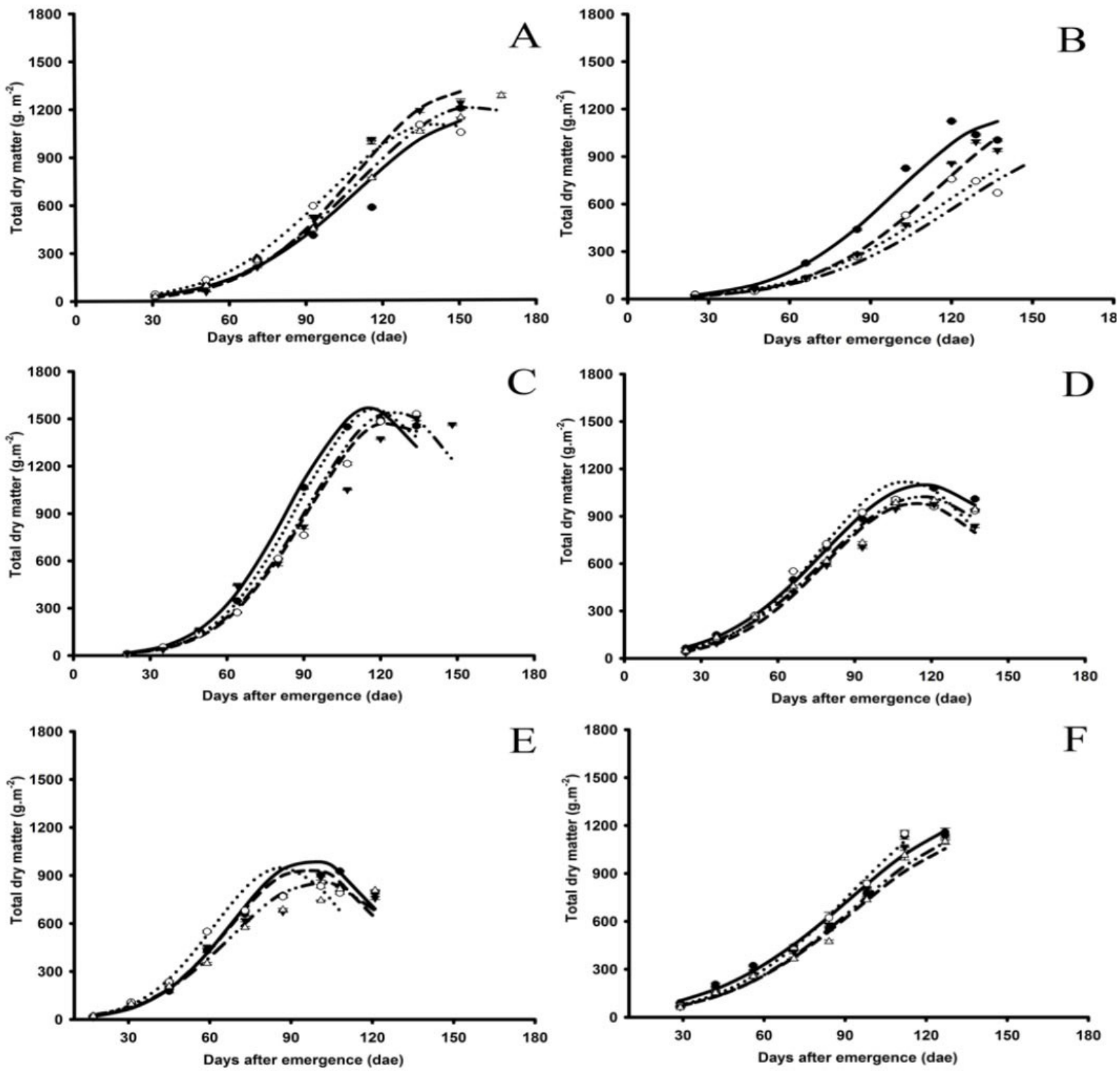

INCA LP 5

Reforma



Figure 2. Dynamics of growth of total dry matter of rice plants after emergence in Los Palacios, province of Pinar del Río, Cuba (A December 2004, B February 2005, C January 2006, D March 2006, E April 2008, F April 2009).

Figura 2. Dinámica de crecimiento de la masa seca total de las plantas de arroz después de la emergencia en Los Palacios, provincia de Pinar del Río, Cuba (A diciembre 2004, B febrero 2005, C enero 2006, D marzo 2006, E abril 2008, F abril 2009).

area duration (LAD) only and negatively with net assimilation rate at the time of the total dry matter growth rate maximum (NAR t TDM GR max), net assimilation rate at the $t$ TDM Gr max (NAR t LAI GR max). 

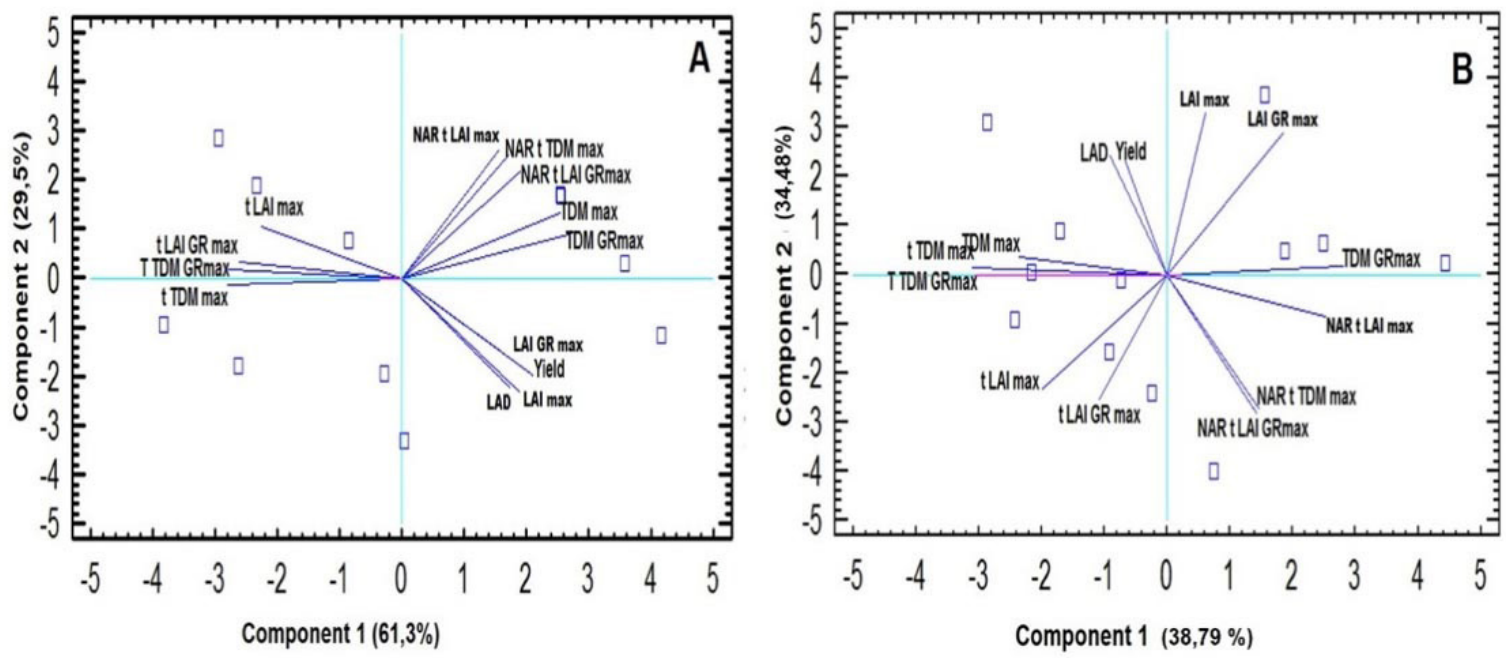

Figure 3. Multivariate analysis between yield and different growth variables of rice plants, in Los Palacios province of Pinar del Río Cuba 2004 to 2009 (A) "rainy season" $n=16$ and (B) "dry season" $n=20$. Time for the maximum value of the total dry matter (t TDM max), maximum total dry matter (TDM max), time for the maximum growth rate of the total dry matter ( $t$ TDM GR max), maximum growth rate of the total dry matter (TDM GR max), time for the maximum leaf area index ( $t$ LAI max), maximum leaf area index (LAI max), time for the maximum growth rate of the leaf area index (LAI GR max), net assimilation rate in time of maximum total dry matter (NAR t LAI max), net assimilation rate in time of maximum growth rate of the total dry matter (NAR t LAI GR max), net assimilation rate in the time of maximum leaf area index (NAR t LAI max), and leaf area duration (LAD).

Figura 3. Análisis multivariado entre el rendimiento y diferentes variables del crecimiento de plantas de arroz, en Los Palacios provincia de Pinar del Río Cuba 2004 a 2009 (A) "época lluviosa" n=16 y (B) "poco lluviosa" n=20. Tiempo para el valor máximo de masa seca total (t TDM max), máxima masa seca total (TDM max), tiempo para la máxima tasa de crecimiento de la masa seca total (t TDM GR max), máxima tasa de crecimiento de la masa seca total (TDM GR max), tiempo para el máximo índice de área foliar (t LAI max), Máximo índice de área foliar (LAI max), tiempo para la máxima tasa de crecimiento del índice de área foliar (LAI GR max), tasa de asimilación neta en el tiempo de máxima masa seca total (NAR t LAI max), tasa de asimilación neta en el tiempo de máxima tasa de crecimiento de la masa seca total (NAR t LAI GR max), tasa de asimilación neta en el tiempo de máximo índice de área foliar (NAR t LAI max), y duración del área foliar (LAD).

Figures 4, 5, 6 y 7 show the results of dry matter variation in different plant organs after anthesis, demonstrating that the process was different taking into account the type of organ, the cultivar and sowing dates and season.

A consist eats dry matter decrease of the third internode, from anthesis to twenty days after it, accounted for more than $90 \%$ of treatments, despite cultivar, plantings date or season (Figure 4A). A similar behavior showed the second internode in more than 50\% of treatments (Figure 4B).

The first internode maintained similar weights in $60 \%$ of treatments during reproductive phase, and in the rest of cases, the weight for this organ increased until ten days after anthesis and decreased towards the end of the phase (Figure 5C). A similar situation was found in peduncle weight variation (Figure 5D).

Flag leaf weight was almost constant in $60 \%$ of treatments. As a whole, a consistent decrease in dry matter after anthesis was found in the sheaths (75\% in "dry" season and $83 \%$ in "rainy" season) and blades of the rest of the leaves in the main stem (67\% in "dry" season and all treatments in "rainy" season) (Figures 6E, 6F, 7G and 7H).

Multivariate analysis among yield and dry matter variation in different plant organs after anthesis, showed for "dry" season (Figure 8A) a positive relationship between yield and panicle dry matter and dry matter variation, and the dry matter decrease of the two lowest internodes (Int 2 and Int 3) and foliar sheaths (FS). A different situation 

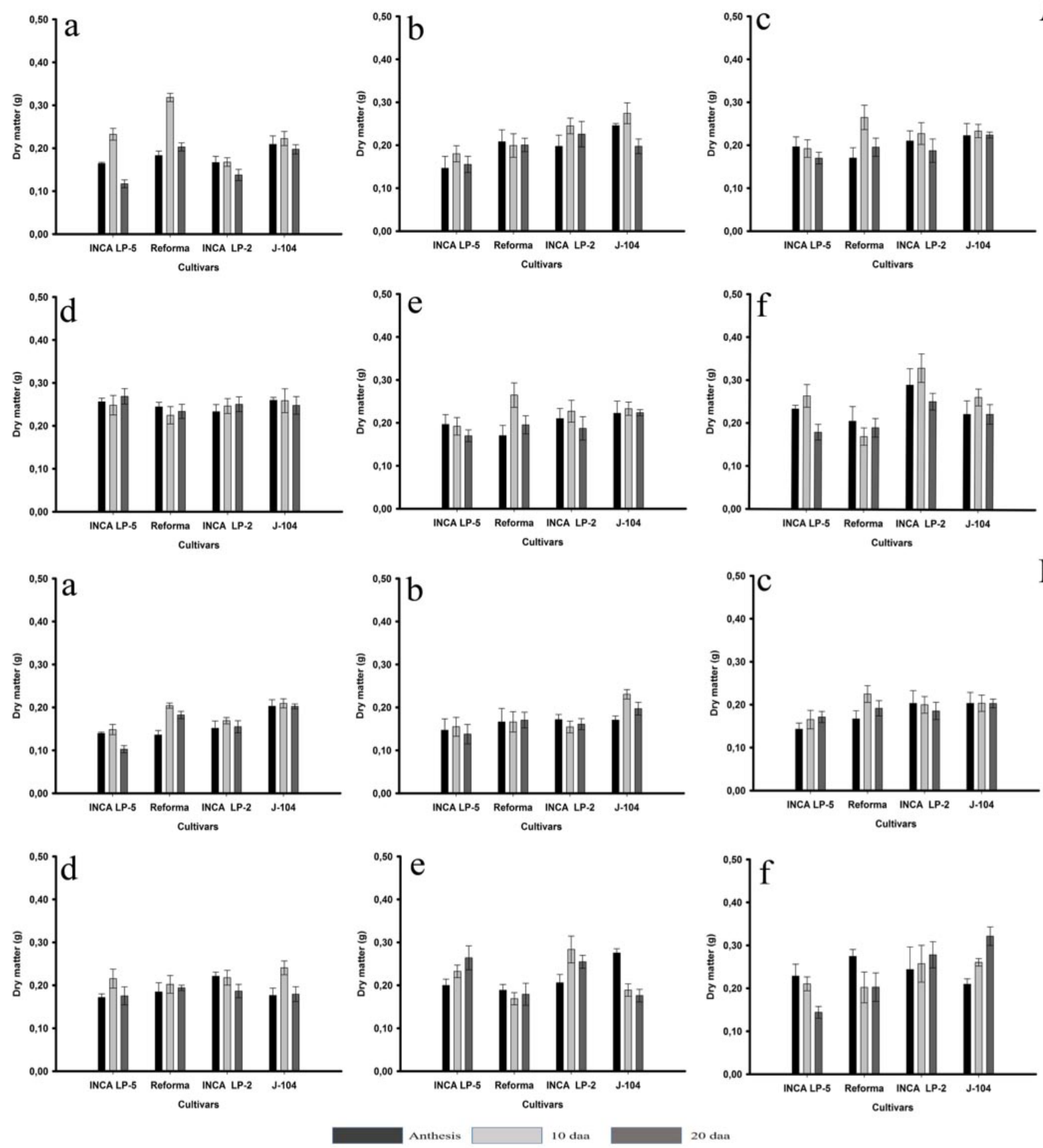

Figure 4. Variation of the dry matter of rice plants in different organs of the plant after the anthesis in Los Palacios, province of Pinar del Río, Cuba (A, third internode, B Second internode, C first internode, D peduncle, to December 2004 , b February 2005, c January 2006, d March 2006, e April 2008, f April 2009).

Figura 4. Variación de la masa seca de plantas de arroz en diferentes órganos de la planta después de la antesis en Los Palacios, provincia de Pinar del Río, Cuba (A, tercer entrenudo, B Segundo entrenudo, C primer entrenudo, D pedúnculo; a diciembre 2004, b febrero 2005, c enero 2006, d marzo 2006, e abril 2008, f abril 2009). 

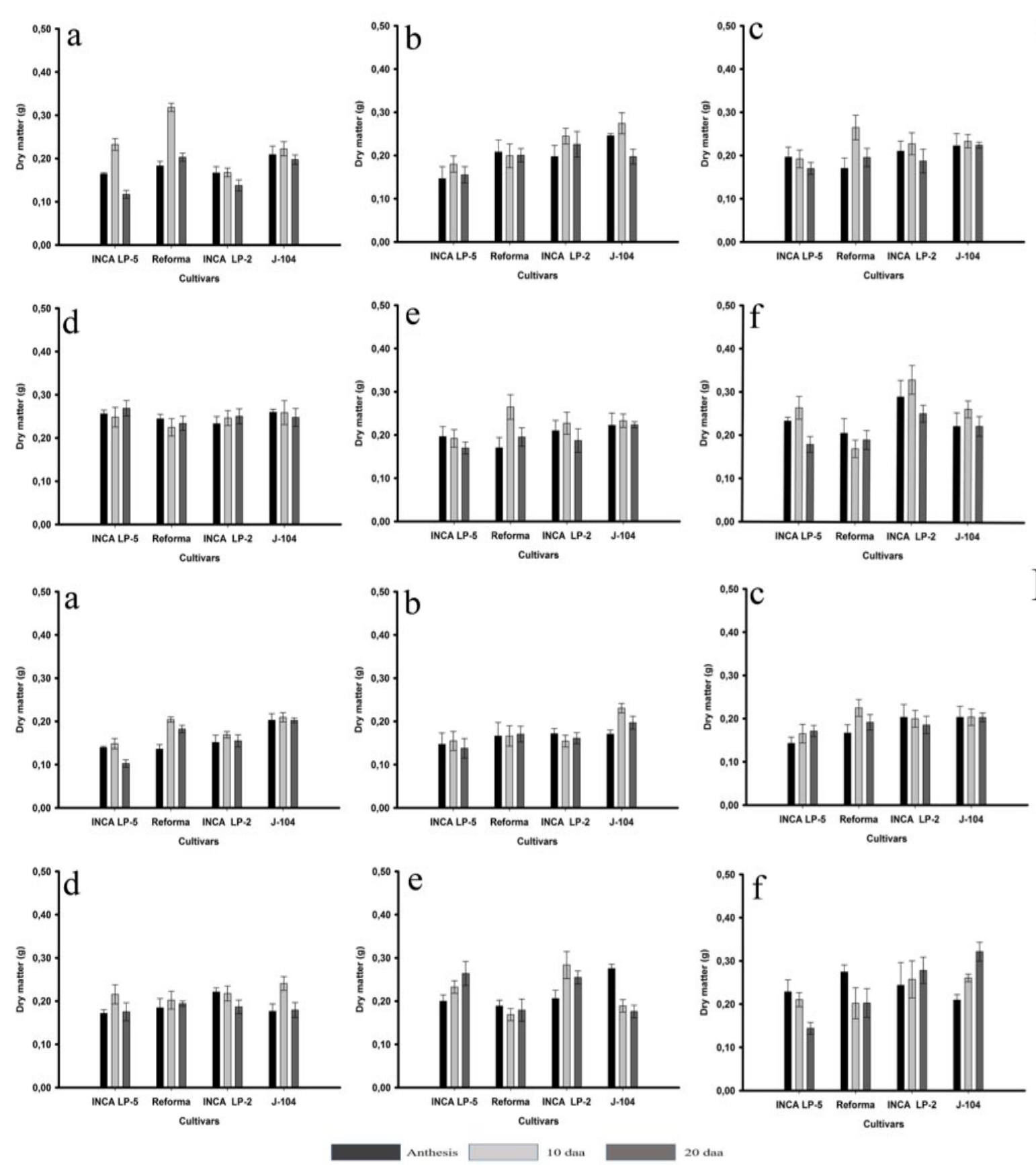

Figure 5. Variation of the dry matter of rice plants in different organs of the plant after the anthesis in Los Palacios, province of Pinar del Río, Cuba (C first internode, D peduncle, to December 2004, b February 2005, c January 2006, d March 2006, e April 2008, f April 2009).

Figura 5. Variación de la masa seca de plantas de arroz en diferentes órganos de la planta después de la antesis en Los Palacios, provincia de Pinar del Río, Cuba (C primer entrenudo, D pedúnculo; a diciembre 2004, b febrero 2005, c enero 2006, d marzo 2006, e abril 2008, f abril 2009). 

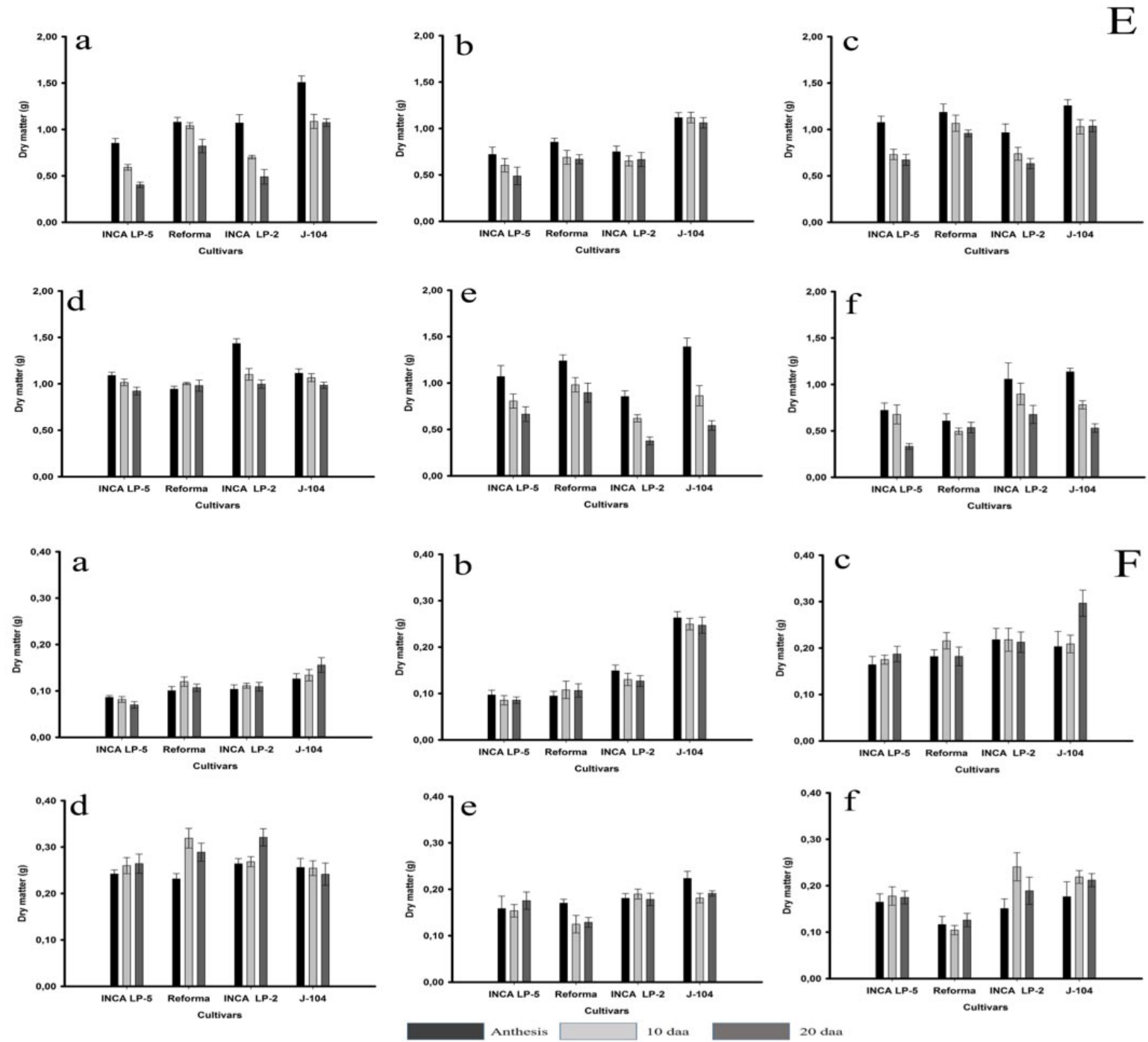

Figure 6. Variation of the dry matter of rice plants in different organs of the plant after the anthesis, in Los Palacios, province of Pinar del Río, Cuba (E: leaf sheaths, F: flag leaf, to December 2004. b February 2005, c January 2006, d March 2006, e April 2008, f April 2009).

Figura 6. Variación de la masa seca de plantas de arroz en diferentes órganos de la planta después de la antesis, en Los Palacios, provincia de Pinar del Río, Cuba (E: vainas de las hojas, F: hoja bandera; a diciembre 2004. b febrero 2005, c enero 2006, d marzo 2006, e abril 2008, f abril 2009).

was found for "rainy" season (Figure 8B), where yield and panicle dry matter, were only positively related to dry matter decrease in the third internode (Int 3).

Anthesis began at different times after emergence taking into account cultivars, from Reforma to LP5, LP 2 and J 104, and these differences were more pronounced in January 2006, April 2008 and April 2009. Panicle dry matter accumulation went on for twenty to thirty days, without a regular behavior among cultivars, sowing dates 

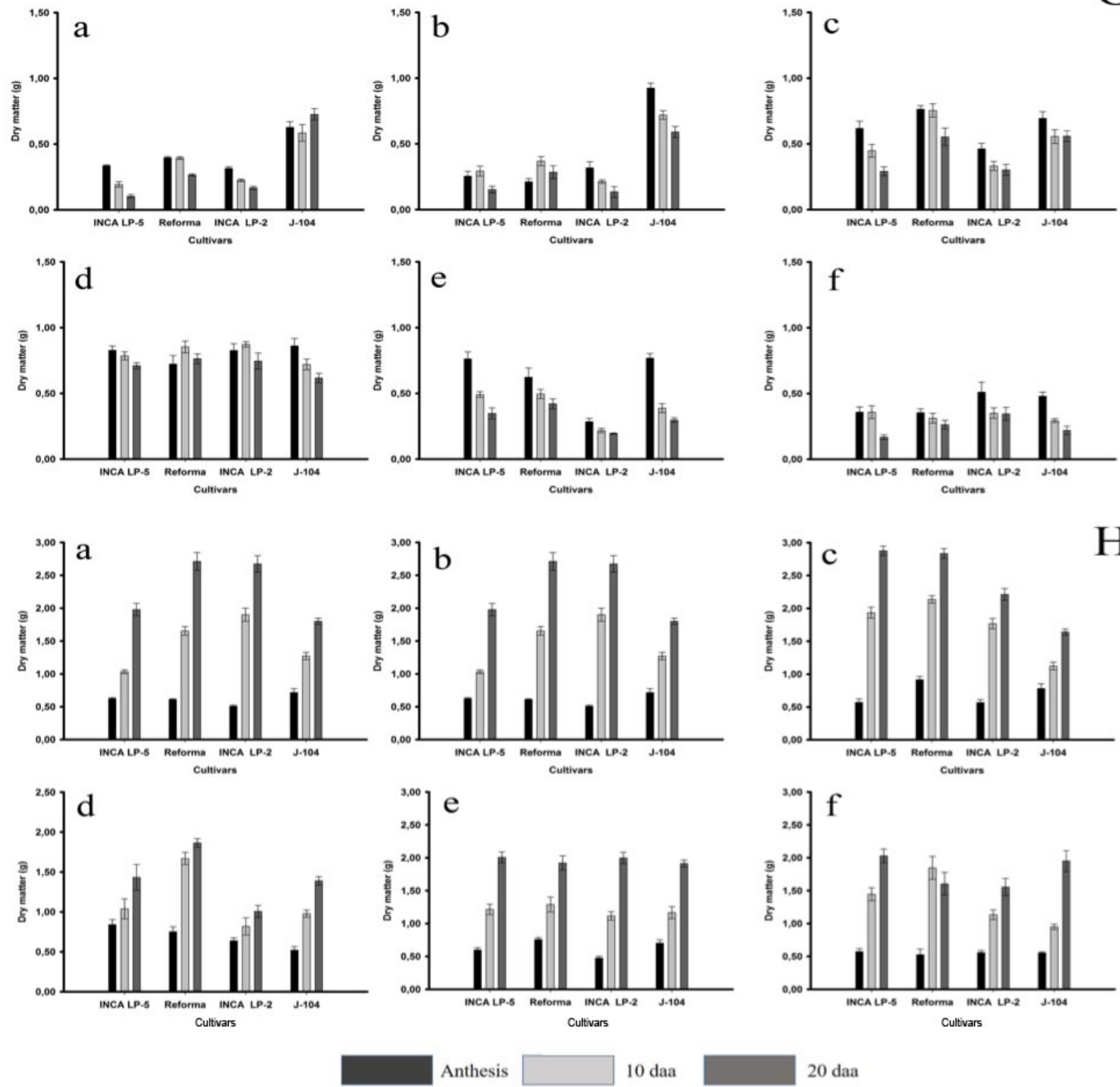

Figure 7. Variation of the dry matter of rice plants in different organs of the plant after the anthesis, in Los Palacios, province of Pinar del Río, Cuba (G: leaves, H: panicle, to December 2004. b February 2005, c January 2006, d March 2006, e April 2008, f April 2009).

Figura 7. Variación de la masa seca de plantas de arroz en diferentes órganos de la planta después de la antesis, en Los Palacios, provincia de Pinar del Río, Cuba (G: hojas, H: panícula; a diciembre 2004. b febrero 2005, c enero 2006, d marzo 2006, e abril 2008, f abril 2009).

or seasons; nevertheless, anthesis began, in all treatments, when LAI was diminishing after attaining its maximum magnitude, earlier in April 2008 and 2009. There were no substantial differences in magnitude for panicle dry weight among seasons, and the weight attained as a general mean was in the order of the $1.9 \mathrm{~g}$ per spikelet. In 

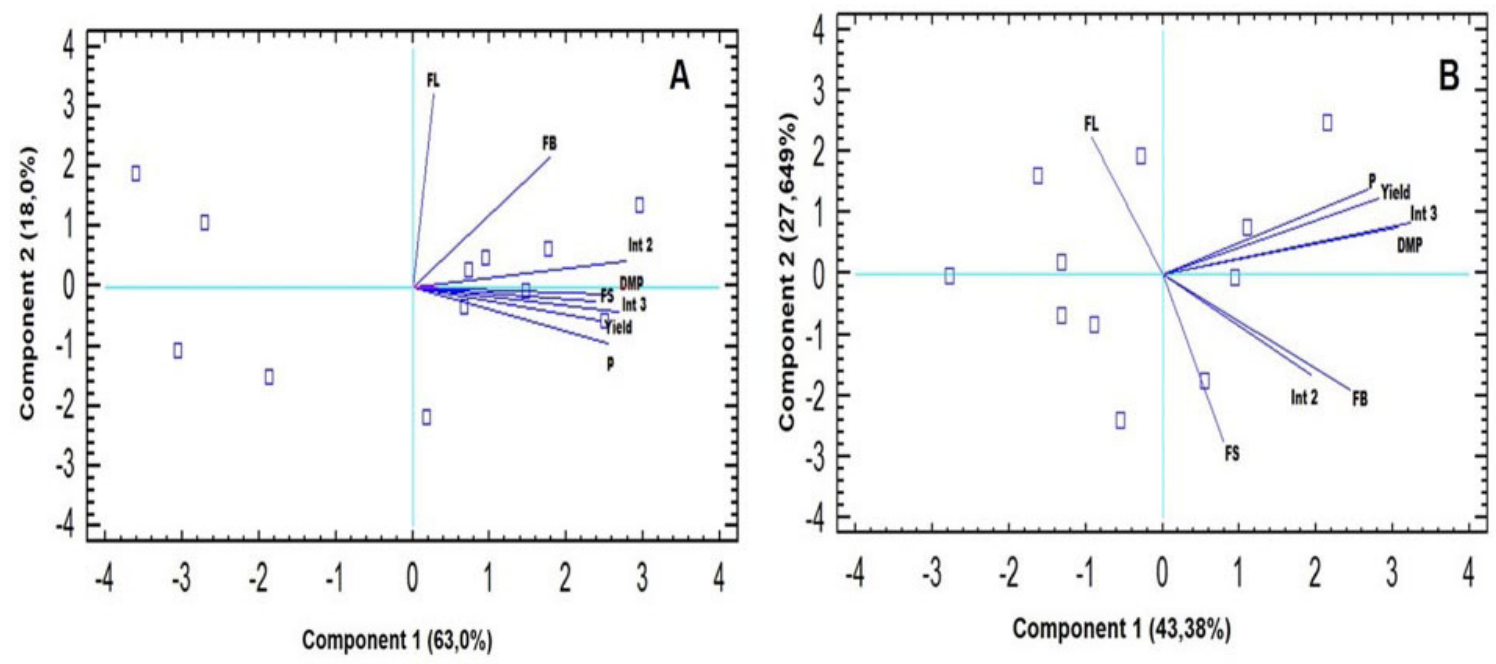

Figure 8. Multivariate analysis between yield and variation of dry matter in different organs of the plant after the anthesis, of rice plants, in Los Palacios province of Pinar del Río Cuba 2004 to 2009 at " less rainy season", B "rainy season ", Third internode (Int. 3), second internode (Int. 2), leaf sheaths (FS), flag leaf (FL), leaves (FB), percentage of variation of the dry matter of the panicle $(\mathrm{P})$, dry matter of the panicle $(\mathrm{S})$.

Figura 8. Análisis multivariado entre el rendimiento y la variación de masa seca en diferentes órganos de la planta después de la antesis, de plantas de arroz, en Los Palacios provincia de Pinar del Río Cuba 2004 a 2009 a "época poco lluviosa", B "época lluviosa", tercer entrenudo (Int. 3), segundo entrenudo (Int. 2), vainas de las hojas (FS), hoja bandera (FL), hojas (FB), porcentaje de variación de la masa seca de la panícula (P), masa seca de la panícula (S).

planting dates of April 2008 and 2009, the growth of individual spikelet was no completed as the cultivar spikelet maximum dry matter was attained after samplings were stopped.

\section{Discussion}

Yield in rice involves several processes such as plant establishment, foliar surface area, and its duration, the total number of tillers and the number of fertile ones, grain number establishment and filling, moreover, stem carbohydrate reserves may be mobilized to grain during the reproductive stage. Meteorological variables interact with former processes to give a complex scheme for yield formation.

Differences in yield and yield components, such as $\mathrm{P} / \mathrm{m}^{2}$ and filled and unfilled grains, among seasons, might be attributable to the prevalence of temperatures during the growing period, due to the fact that plants in the "rainy" season developed with higher temperatures.

Different studies stated the variability of Pan $\mathrm{m}^{-2}$ and in general, indicate it was the main cause limiting yield, together with the number of full grains per panicle (MINAG, 2008). Briceño and Álvarez (2010) pointed out that panicle related variables, such as primary and secondary branches, number of full grains, grain weight, varied according to different factors such as planting season, plant nutrition and mainly, cultivars and their growth characteristics.

These results showed the need for adjusting planting densities according to cultivar growth characteristics and planting season, in a particular locality in order to obtain an adequate number of fertile stems and ensure maximum yields. Feature informed by Polón et al. (2012), due to the direct relation between the plant number per area and 
yield (Cuevas, 1999; Polón and Castro, 1999; Yamagata, 1999; Polón et al., 2003), and also indirectly due to the fact that this variable, as well as the foliar surface per plant, determine the LAI.

Growth variables and parameters related in a different way with yield among crop seasons. In both seasons, yield was related positively with leaf area duration (LAD) and this variable has two components, its magnitude and the persistence during the growth period, the former being more important in "dry" season as yield was also positively related to the maximum value attained for plant foliar surface and the moment leaf area index growth rate maximum, and the sooner the maximum LAI is obtained and plant dry matter accumulation occurs, the higher the yield. For "rainy" season a different situation was obtained due to an indirect relation to the foliar surface magnitude where more important is its persistence and the lesser the net assimilation rate, at different moments of growth. No other growth-related variables were related to yield, though Aderi (2016) obtained that CGR increased up to 9-12 weeks after sowing and began to decline at twelve to fifteen weeks after sowing. They obtained a positive correlation between rice biomass, CGR, and yield.

LAI dynamics showed a decrease at its final stage of growth, when spikelets began to grow, due mainly to leaf senescence and possible to the translocation of reserves to the growing panicle. The higher LAI values for short cycle cultivars in the "dry" season are in correspond with higher yield in those cultivars in that season. The former demonstrates the LAI importance and its relation to yield (Maqueira et al., 2014), supported by the positive relation between yield and foliar surface attributes for both planting seasons.

Differences in time for the leaf area index maximum ( $\mathrm{LAI}$ max) among seasons are related to the plant growth response to temperature, as established by Moradpour et al. (2013) as the main factor determining growth rate, being faster in the "rainy" season (higher temperatures) compared with the "dry" season (lower temperatures); nevertheless, values of LAI maximum (LAI max) were higher in the "dry" season.

The former results empathize that, in "dry" season greater yields will be obtained when plants achieve high values for maximum LAI, LAD and LAI GR maximum (Figure 3A) and these should be attained earlier during plant development. While for "rainy" season (Figure 3B), the better positive relation with yield was obtained with LAD and maximum LAI only. These results are logic due to the role that foliar surface related variables have in carbon assimilation in the plant.

Differences among cultivars of different cycle were evident for LAI in "dry" season, showing short cycle cultivars higher values for this variable compared with medium cycle ones. These differences among cultivars were not shown in "rainy" season. In general, different authors found higher LAI values for short cycle cultivars compared to medium cycle ones (Polón et al., 2003; 2012), in a 6 to 8 range, higher to the obtained in the present research.

There is a general agreement that LAI values higher than four are adequate for obtaining yields higher than $5 \mathrm{t} / \mathrm{ha}$, in general, higher to the ones found in the present research. The strong relation between yield and LAI has been observed by different authors informing an increase in yield with the increase in LAI (Yamagata, 1999; Reddy et al., 2000; Moradpour et al., 2013), although others inform no benefits with the increase on LAI (Cuevas, 1999). For a specific cultivar in a specific environment, increases in LAI should increase yield to an optimum then, the mutual shading of leaves diminishes the plant photosynthetic activity and yield, due to the positive relation between the maximum radiation use efficiency and LAI, nevertheless optimal RUE generally is attained with a LAI of 5 and a decrease with higher values.

Attention should be payed, not only to LAI, but also to leaf disposition in relation to stem because an excess of foliar area per unit of cultivated surface, due to an excessive tiller number or heavy nitrogen dressings, may be the cause of a reduction in yield due to mutual shading (San-oh et al., 2004).

Some authors underlined that high yielding cereals are characterized for an optimal photosynthetic development during vegetative growth and by a high rate of dry matter production during reproductive stage, which depends on an optimal LAI, a prolonged foliar activity and a high rate of photosynthesis (Xiao et al., 2007; Soto et al., 2009). In addition to the above-mentioned factors, for the maximum interaction of solar radiation, it is important to consider 
the duration of LAI and leaf area duration (LAD) during the plant growing season. Soto and Hernández (2012), emphasize that high yield in sorghum was related to a LAI and LAD.

The explanation for the negative relation between NAR in different growth periods and yield in "rainy" season it's a little more complex. The NAR is an indicator of the plant efficiency to convert radiation energy into biomass, through the foliar surface and the balance among synthesis and degradation processes. From Figure $3 \mathrm{~B}$ it can be deduced that lower values for NAR may be related to higher values in the foliar surface in the moment of LAI GR max and TDM max accumulation and agrees with the positive relationship found between yield and LAD.

There was no regularity for dry matter per plant among cultivars, planting dates or seasons and none apparent relation was found between dry matter per plant and LAI. Although in the present research, leaf senesces was initiated earlier in sowing dates of "rainy" season compared with the dates in "dry" season and maximum dry weight for spikelets were attained earlier, showing maximum values in the final stages of growth (reproduction stage).

Plant dry matter accumulation is the result of the balance of carbon metabolism between biosynthesis and catabolized carbon, and taking into account that rice is a $\mathrm{C}_{3}$ plant where carbon losses due to respiration and photorespiration are greater than in $\mathrm{C}_{4}$ plants, mainly when there is a rise in air temperatures (Gowik and Westhoff, 2011; Evans, 2013). The former could bring limitations in plant growth, mainly when leaf number and size, and hence plant foliar surface, present limitations carrying a lesser radiation interception and photosynthetic activity per plant, and radiation use efficiency (RUE).

During reproductive stage, the fate of reserves accumulated during vegetative growth could be respiration, translocation to other plant parts, or both. Mohammed and Tarpley (2009) found the portion of stem reserves used in the respiration process is negligible, indicating that plant respiration uses as a substrate, recently synthesized photo assimilates through photosynthesis. They stated that respiration reaches a maximum value early in the grain filling process, declining significantly towards the middle of the stage. The former gives rise to the idea that stem dry weight losses, from anthesis to physiological maturity, is partitioned into growing grains.

During filling grain stage conditions that limited the plant source, such as a lesser foliar surface or conditions that limit photosynthetic activity, do not fulfill sink demands and a carbon remobilization from the stem to grains is established, as demonstrated by Esmaeilpour-Jahromi et al. (2012) and Bazargani et al. (2012) for wheat.

Results pointed out to the third internode of rice plant as an important reserve source, which is mobilized and used for rice grain growth, coinciding with Ehdaie et al. (2006a; 2006b; 2008), who identified, for this purpose, the basal internodes in wheat plants, then the plant guarantees the sink demands through the mobilization of reserves previously allocated in different plant organs.

The contribution analysis of stems reserves to different sinks among the plant during the final phases of growth is complex due to they occupy an intermediate position between the principal sink or source organs, and also taking into account their different capacity of storage and reserve mobilization.

During grain filling stage the plants developed with warmer temperatures in both seasons, but in "dry" season with a larger sink capacity, plants mobilized reserves from a greater number of organs than in "rainy" season (Figures 6 and 7).

Little information is available for rice about genotypic responses to warm night temperature $\left(30 \pm 0.5^{\circ} \mathrm{C}\right)$ in situ (Mohammed and Tarpley, 2014) In temperature-controlled field chambers, with 36 varieties from all over the world, stated that negative effect of high night temperature on grain yield was partially due to low biomass and low harvest index, a mild increase in night temperature during the reproductive growth stage reduced yield was attributed to decrease in grain weight, harvest index, grain filling and spikelets number per panicle. A $4{ }^{\circ} \mathrm{C}$ difference between $\operatorname{HNT}\left(30 \pm 0.5^{\circ} \mathrm{C}\right)$ and $\operatorname{LNT}\left(25 \pm 0.5^{\circ} \mathrm{C}\right)$ in the field chamber system causes $10 \%$ grain yield decrease on average of four consecutive seasons.

Several authors demonstrated the negative effects of higher temperatures in grain yield (Kim et al., 2011; Zhang et al., 2013; Mohammed and Tarpley, 2014). Furthermore, Nyang`aut et al. (2014) using the CERES rice 
model ( $\mathrm{v}$ 4.5) of the DSSAT modeling system revealed that increase in both maximum and minimum temperatures (the latter has a deeper impact) affected the grain yield of two cultivars and increasing solar radiation an increasing impact of yield was attained in two rice cultivars.

Elevated temperatures influence rice yield and quality mainly during reproductive stages (Jagadish et al., 2007; $2008 ; 2010)$. The high temperatures cause yield loss in rice by increasing respiration and energy consumption while decreasing seed assimilation, grain weight and harvest index (Zakaria et al., 2002; Prasad et al., 2006; She et al., 2010). Furthermore, warm weather during ripening reduces grain quality (Chun et al., 2009; Kobayashi et al., 2007; Tabata et al., 2007; Zhu et al., 2013).

Grain filling depends on sink activity under high temperature. Then, attention should be pay to the five enzyme systems playing a major role in grain rice endosperm development: sucrose synthase, invertase, starch synthase, glucose diphosphate phosphorylase and starch branching enzyme (Nakamura et al., 1989; Kato, 1995; Yang et al., 2001; Zhang et al., 2011), among the 33 involved in the process (Nakamura et al., 1989; Zhang et al., 2011).

Radiation regime, interacting with temperature, over the growing season or in different phenological stages, is the other meteorological aspect to take into account. In general, agricultural yield increases with higher radiation availability during the growing season, mainly during the final growth stages, overall at the reproductive phase. Hirai (2008) and Pérez-de-Vida (2010) highlight this phenological stage in relation to radiation, due to the fact that is the one when rice requirements for radiation are critical. In the present study, "dry" season was characterized by lower radiation inputs at early stages of growth that "rainy" season, but both ended, at reproductive stage, with similar values (Figure 1). Dingkuhn et al. (2015) differences in RUE are partly attributable to variation in terminal senescence which is strongly environment dependent. Huang et al. (2016) results for hybrid rice suggested that higher Radiation Use Efficiency (RUE) and grain yield can be achieved by improving leaf photosynthetic traits including chlorophyll a content, Fv/Fm, $\phi$ PSII and Rubisco content.

Working with autotetraploid and diploid rice including indica and japonica genotypes, Shahid et al. (2013), in two sowing seasons found that greater amount of solar radiation $\left(14.5 \mathrm{MJ} / \mathrm{m}^{2} /\right.$ day mean daily solar radiation), photothermal quotient and suitable temperature (around $25.6{ }^{\circ} \mathrm{C}$ ) contributed to higher yield, number of panicles per plant, filled grains, flag leaf area and dry matter production. A major contribution to sink and biomass accumulation, was found increased grain yield compared with a season with reduced amounts of solar radiation $\left(11.8 \mathrm{MJ} / \mathrm{m}^{2} /\right.$ day mean daily solar radiation), a daily maximum temperature equal or higher than $35^{\circ} \mathrm{C}$ for more than three consecutive days at flowering.

The results confirm differences in the pattern of panicle dry matter increase between seasons: in "dry" season, panicle active growth started since anthesis in more than $50 \%$ of cases, while in "rainy" season it started ten days after anthesis where, in general, dry matter of different plant parts diminished, mainly from the third internode (Figures 4 and 5). This suggests that grain filling was affected by photosynthate availability and it was necessary to mobilize reserves stored previously in different plant organs, more pronounced in "dry" season. Where the dry matter decrease of more organs (Int.2, Int.3, foliar sheaths) (Figure 8A) contributed to yield and panicle dry matter.

Several studies have demonstrated that sink activity determines carbohydrate unloading in the phloem, what could influence the process of reserve utilization from stems and sheaths. Different authors pointed out that sink activity increases at $10 \mathrm{dda}$ and panicle dry weight increases significantly (Nagata et al., 2001; Okawa et al., 2003; Yan and Zang, 2006; 2010). Grain yield of rice is determined by sink size (spikelets per unit land area), spikelet filling percentage and grain weight. Sink size is considered the primary determinant of rice yield.

Currently, limited information is available on the critical factors that explain the yield gap between high and normal-yielding subtropical environments. Such information would be useful for understanding the constraints of rice yield potential in the normal-yielding subtropical environment and for determining the plant characteristics that contribute to high yields. Huang et al. (2013) studies suggest that further improvement in both sink and source should be possible in the normal-yielding subtropical environment if new rice cultivars are to bred by selection for 
tillering (tiller number and size), and developing cultivars with high spikelet filling percentage and grain weight may also be a feasible approach to achieve high rice yield.

Differences in plant growth were found by Agele et al. (2015), in two monthly consecutive sowing dates, significant for most of the traits measured (root and shoot weight, leaf area, plant height, number of tillers, weights of panicle and 100-seed and harvest index). Differences in shoot biomass and seed yield production among sowing dates were explained by a combination of weather parameters, where seed yield was negatively and highly associated with evaporative demand, thermal time and minimum temperatures.

Panicle number per $\mathrm{m}^{2}\left(\mathrm{Pan} / \mathrm{m}^{2}\right)$, as well as total grains per panicle (G/pan) (Table 1), were lower (although in an acceptable range) compared with their genetic characterization under optimal growth conditions (Pérez, 1998; MINAG, 2005), as well as LAI. García et al. (2010), working with J 104 cultivar under semi-controlled conditions showed the superiority of "dry" season in a relation to plant yield and the results of the present work generalize the statement to other cultivars differing in growth cycle. Nevertheless, increased grain number per panicle, due to its strength and activity, could increase demands from the sources, leaves, and reserves allocated previously in the internodes; in this sense, ambient conditions and plant growth stage, mainly leaves surface at the beginning of grain filling, play an important role to answer this increment.

It is important to mention that rice plants shown a trait-trait compensation mechanism among yield components (Dingkuhn et al., 2015), regulated by cultivar characteristics and growing conditions (Morejón et al., 2005; 2012) and the variability found in yield and its components in the present study could be related with the duration of phenological phases and prevailing meteorological conditions during their development.

\section{Conclusions}

Rice yields were related to vegetative growth traits connected to the foliar surface and its duration and with plant dry matter traits. The yield was also related to dry matter variation in different organs after anthesis, mainly in the third internode for both planting seasons. Breeders, in order to increase potential yields, may focus their attention in growth traits during vegetative stages, such as plant foliar surface and dry matter of the third internode, among others, and on post-floral physiological processes, namely dynamics of light interception, carbon assimilation and maintenance burden, trying to combine them in one cultivar for high yielding capacity, which is up to now a major challenge.

\section{Cited literature}

Acevedo, M.A., W.A. Castrillo, y U.C. Belmonte. 2006. Origen, evolución y diversidad del arroz. Agron. Trop. 56:151-170.

Aderi, O.S. 2016. Density and cultivar effects on the biomass and Crop Growth Rate of upland rice in Uyo southeastern Nigeria. Am. J. Exp. Agric. 10:1-11. doi:10.9734/AJEA/2016/20597

Agele, S.O., A.T.B. Aderibigbe, and T.O. Oladitan. 2015. Yield traits and water productivity responses among rice varieties (Oryza sativa L.) grown in a Fadama ecosystem in Akure, southwestern Nigeria. Am. J. Exp. Agric. 5:435-449. doi:10.9734/AJEA/2015/6197

Akinbile, C.O. 2013. Assessment of the CERES-Rice model for rice production in Ibadan, Nigeria. Agric. Eng. Int. CIGR J. 15:19-26.

Álvarez, R., M. Pérez, y E. Reyes. 2008. Evaluación comparativa de híbridos y variedades de arroz en los llanos centroccidentales de Venezuela. Agron. Trop. 58:101-110. 
Amador, M., y R. Peña. 1986. Tamaño óptimo de muestra para evaluar rendimiento y sus parámetros en el cultivo del arroz en la Estación Experimental de Jucarito. Cienc. Téc. Agric. Arroz 5(2):41-62.

Bazargani, M.M., M.R. Hajirezaei, G.H. Salekdeh, A.A. Bushehri, M. Falahati-Anbaran, F. Moradi, M.R. Naghavi, and B. Ehdaie. 2012. A view on the role of metabolites in enhanced stem reserves remobilization in wheat under drought during grain filling. Autral J. Crop Sci. 6:1613-1623.

Briceño, I., y L.E. Álvarez. 2010. Evaluación de un sistema de preparación de suelo y siembra en el cultivo del arroz (Oryza sativa L.). Cienc. Téc. Agric. Arroz 28(1):16-24.

Bruinsma, J. 2009. The resource outlook to 2050. In: FAO, editor, Expert Meeting on "How to Feed the World in 2050". FAO, Rome, ITA. p. 1-33.

Canfalonieri, R., S. Bregaglio, A.S. Rosenmund, M. Acutis, and I. Savin. 2011. A model for simulating the height of rice plants. Eur. J. Agron. 34:20-25. doi:10.1016/j.eja.2010.09.003

Chun, A., J. Song, K.J. Kim, and H.J. Lee. 2009. Quality of head and chalky rice and deterioration on eating quality by chalky rice. J. Crop Sci. Biotechnol. 12:239-244. doi:10.1007/s12892-009-0142-4

CIAT. 1985. Investigación y producción de arroz. Crecimiento y etapas de desarrollo de la planta de arroz. CIAT, Palmira, COL.

Cuevas, A. 1999. Manejo de la soca de arroz. Santa Fé de Bogotá-Colombia. Arroz 48:16-18.

Dingkuhn, M., M.R.C. Laza, U. Kumar, K.S. Mendez, B. Collard, K. Jagadish, R.K. Singh, T. Padolina, M. Malabayabas, E. Torres, M.C. Rebolledo, B. Manneh, and A. Sow. 2015. Improving yield potential of tropical rice: Achieved levels and perspectives through improved ideotypes. Field Crops Res. 182:43-59. doi:10.1016/j.fcr.2015.05.025

Ehdaie, B., G.A. Alloush, M.A. Madore, and J.G. Waines. 2006a. Genotypic variation for stem reserves and mobilization in wheat. I. Postanthesis changes in internode dry matter. Crop Sci. 46:735-746. doi:10.2135/cropsci2005.04-0033

Ehdaie, B., G.A. Alloush, M.A. Madore, and J.G. Waines. 2006b. Genotypic variation for stem reserves and mobilization in wheat. II. Postanthesis changes in internode water-soluble carbohydrates. Crop Sci. 46:2093-2103. doi:10.2135/ cropsci2006.01.0013

Ehdaie, B., G.A. Alloush, and J.G. Waines. 2008. Genotypic variation in linear rate of grain growth and contribution of stem reserves to grain yield in wheat. Field Crops Res. 106:34-43. doi:10.1016/j.fcr.2007.10.012

Esmaeilpour-Jahromi, M., A. Ahmadi, J.E. Lunn, A. Abbasi, K. Poustini, and M. Joudi. 2012. Variation in grain weight among Iranian wheat cultivars: the importance of stem carbohydrate reserves in determining final grain weight under source limited conditions. AJCS 6:1508-1515.

Evans, L.T., and R.A. Fischer. 1999. Yield potential: its definition, measurement, and significance. Crop Sci. 39:1544-1551. doi:10.2135/cropsci1999.3961544x

Evans, J.R., and S. von-Caemmerer. 2013. Temperature response of carbon isotope discrimination and mesophyll conductance in tobacco. Plant Cell Environ. 36:745-756. doi:10.1111/j.1365-3040.2012.02591.x

FAO. 2013. United Nations statistical database. FAOSTAT, ITA.

Fischer, T., D. Byerlee, and G.O. Edmeades. 2014. Crop yields and global food security: Will yield increase continue to feed the world? ACIAR Monograph. Australian Centre for International Agricultural Research, Canberra, AUST.

García, A., M. Dorado, I. Pérez, y E. Montilla. 2010. Efecto del déficit hídrico sobre la distribución de fotoasimilados en plantas de arroz (Oryza sativa L.). Interciencia 35:47-54.

García, D., W. Torres, y M. Núñez. 1998. Análisis del crecimiento de callos de Coffea canephora var. Robusta en presencia del análogo de brasinosteroide MH5. Cultivos Trop. 19:55-60. 
Gowik, U., and P. Westhoff, 2011. The path from C3 to C4 photosynthesis. Plant Physiol. 155:56-63. doi:10.1104/pp.110.165308

Hernández, A., J.M. Pérez, D. Bosch, y L. Rivero. 1999. Nueva versión de la clasificación genética de los suelos de Cuba. AGRINFOR, La Habana, CUB.

Hernández, N., y C.F. Soto. 2012. Influencia de tres fechas de siembra sobre el crecimiento y la relación fuente-demanda del cultivo del maíz (Zea mays L.) Cultivos Trop. 33:28-34.

Hernández, N., y C.F. Soto. 2013. Determinación de índices de eficiencia en los cultivos de maíz y sorgo establecidos en diferentes fechas de siembra y su influencia sobre el rendimiento. Cultivos Trop. 34:24-29.

Hirai, Y., K. Tagami, K. Hamagami, S. Uchida, S. Inaba, and K. Mori. 2008. Evaluation of environment on rice production for the rice terraces in Hoshino Village. J. Fac. Agr. Kyushu Univ. 53(1):95-100.

Huang, M., L. Jiang, B. Xia, Y. Zou, P. Jiang, and H. Ao. 2013 Yield gap analysis of super hybrid rice between two subtropical environments. Aust. J. Crop. Sci. 7:600-608.

Huang, M., S. Shan, X. Zhou, J. Chen, F. Cao, L. Jiang, and Y. Zou. 2016. Leaf photosynthetic performance related to higher radiation use efficiency and grain yield in hybrid rice. Field Crop Res. 193:87-93. doi:10.1016/j.fcr.2016.03.009

Iizumi, T., H. Sakuna, M. Yokozawa, J.J. Luo, A.J. Challinor, M.E. Brown, G. Sakurai, and T. Yamagata. 2013. Prediction of seasonal climate-induced variations in global food production. Nat. Clim. Change 2:186-189.

Iizumi, A.T., M. Yokozawa, and M. Nishimori. 2011. Probabilistic evaluation of climate change impacts on paddy rice productivity in Japan. Clim. Change 107:391-415. doi:10.1007/s10584-010-9990-7

Jagadish, S.V.K., P.Q. Craufurd, and T.R. Wheeler. 2008. Phenotyping parents of mapping populations of rice for heat tolerance during anthesis. Crop Sci. 48:1140-1146. doi:10.2135/cropsci2007.10.0559

Jagadish, S.V.K., P.Q. Craufurd, and T.R. Wheeler. 2007. High temperature stress and spikelet fertility in rice (Oryza sativa L.) J. Exp. Bot. 58:1627-1635. doi:10.1093/jxb/erm003

Jagadish, S.V.K., R. Muthurajan, R. Oane, T.R. Wheeler, S. Heur, J. Bennet, and P.Q. Craufurd. 2010. Physiological and proteomic approaches to address heat tolerance during anthesis in rice (Oryza sativa L.). J. Exp. Bot. 61:143-156. doi: $10.1093 / \mathrm{jxb} / \mathrm{erp} 289$

Kato, T., 1995. Change of sucrose synthase activity in developing endosperm of rice cultivars. Crop Sci. 35:827-831. doi:10.2135/cropsci1995.0011183X003500030032x

Kim, J., J. Shon, C.K. Lee, W. Yang, Y. Yoon, W.H. Yang, Y.G. Kim, and B.W. Lee. 2011. Relationship between grain filling duration and leaf senescence of temperate rice under high temperature. Field Crops Res. 122:207-213. doi:10.1016/j. fcr.2011.03.014

Kobayashi, A., B. Genliang, Y. Shenghai, and K. Tomita. 2007. Detection of quantitative trait loci for white-back and basalwhite kernels under high temperature stress in japonica rice varieties. Breed. Sci. 57:107-116. doi:10.1270/jsbbs.57.107

Maqueira, L.A., D. González, W. Torres, y S. Masaaki. 2014. Evaluación del comportamiento de variables del crecimiento en variedades de arroz de tipo Japónica bajo condiciones de secano favorecido. Cultivos Trop. 35:43-49.

Merlos, F.A., J.P. Monzon, J.L. Mercau, M. Taboada, F.H. Andrade, A.J. Hall, E. Jobbagy, K.G. Gassman, and P. Grassini. 2015. Potential for crop production increase in Argentina through closure of existing yield gaps. Field Crops Res. 184:145-154. doi:10.1016/j.fcr.2015.10.001

MINAG (Ministerio de Agricultura y Riego). 2005. Instructivo técnico cultivo de arroz. Instituto de Investigaciones del Arroz. La Habana, CUB. 
MINAG (Ministerio de Agricultura y Riego). 2008. Instructivo técnico cultivo de arroz. Instituto de Investigaciones del Arroz, La Habana, CUB.

Mohammed, A.R., and L. Tarpley. 2014. Differential response of two important Southern US rice (Oryza sativa L.) cultivars to high night temperature. Aust. J. Crop Sci. 8:191-199.

Mohammed, A.R., and L. Tarpley. 2009. Impact of high nighttime temperature on respiration, membrane stability, antioxidant capacity, and yield of rice plants. Crop Sci. 49:313-322. doi:10.2135/cropsci2008.03.016

Moradpour, S., R. Koohi, M. Babaei, and G. Khordhidi. 2013. Effect of planting date and planting density on rice yield and growth analysis (Fajr variety). Int. J. Agric. Crop Sci. 5-3:267-272.

Morejón, R., J.J. Hernández, y S. Díaz. 2005. Comportamiento de variedades comerciales de arroz (Oryza sativa L.) en cuatro granjas del Complejo Agroindustrial Arrocero Los Palacios. Cultivos Trop. 26:77-81.

Morejón, R., J.J. Hernández, y S.H. Díaz. 2012. Comportamiento de tres variedades comerciales de arroz en áreas del Complejo Agroindustrial Arrocero «Los Palacios». Cultivos Trop. 33:46-49.

Nagata, K., S. Yoshinaga, J. Takanashi, and T. Terao. 2001. Effects of dry matter production of non-structural carbohydrates and nitrogen application on grain filling in rice cultivar Takanari, a cultivar bearing a large number of spikelets. Plant Prod. Sci. 4:173-183.

Nakamura, Y., K. Yuki, and S.Y. Park. 1989. Carbohydrate metabolism in the developing endosperm of rice grains. Plant Cell Physiol. 30:833-839. doi:10.1093/oxfordjournals.pcp.a077813

Nyang`au, W.O., B.M. Mati, K. Kalamwa, R.K. Wanjogu, and I.K. Kiplagat. 2014. Estimating rice yield under changing weather conditions in Kenya using CERES rice model. International J. Agron. 22:525-533. doi:10.1155/2014/849496.

Okawa, S., A. Makino, and T. Mae. 2003. Effect of irradiance on the partitioning of assimilated carbon during the early phase of grain filling in rice. Ann. Bot. 92:357-364. doi:10.1093/aob/mcg147

Pérez, N. 1998. Variedad de arroz INCA LP-2. Cultivos Trop. 19:67.

Pérez-de-Vida, F. 2010. Aspectos de la ecofisiología del cultivo de arroz en Uruguay: II. Importancia de la fecha de siembra en la productividad En: INIA, editor, Ecofisiología del cultivo de arroz. Resultados Experimentales 2009-2010. INIA Treinta y Tres, URU. p. 8-12.

Polón, R., y R. Castro. 1999. Aplicación del estrés hídrico como alternativa para incrementar el rendimiento en el cultivo del arroz (Oryza sativa L.). Cultivos Trop. 20:37-39.

Polón, R., I. Castro, N. Pérez, E. Cristo, R. Morejón, y Y. Parra. 2003. Influencia de la altura de la soca en el rendimiento del arroz (Oryza sativa L.) en una variedad de ciclo corto. Cultivos Trop. 24:55-57.

Polón, P.R., A.R. Castro, S.M. Ruiz, y L. Maqueira. 2012. Práctica de diferentes alturas de corte a cultivo de rebrote y su influencia en el rendimiento del arroz (Oryza sativa L.) en una variedad de ciclo medio. Cultivos Trop. 33:59-62.

Prasad, P.V.V., K.J. Boote, L.H. Allen, J.E. Sheeny, and J.M.G. Thomas. 2006. Species, ecotype and cultivar differences in spikelet fertility and harvest index of rice in response to high temperature stress. Field Crop Res. 95:398-411. doi:10.1016/j.fcr.2005.04.008

Reddy, T.G., M. Mahadevappa, and K.R. Kurcarni. 2000. Rice ratoon crop management in hilly regions of Karmataca, India. Int. Rice Res. Newslett. 4:22-23.

Ruiz, M., G.S. Díaz, y R. Polón. 2005. Influencia de las tecnologías de preparación de suelo cuando se cultiva arroz (Oryza sativa L.). Cultivos Trop. 26:45-52. 
San-oh, Y., Y. Mano, T. Okawa, and T. Hirasawa. 2004. Comparison of dry matter production and associated characteristics between direct-sown and transplanted rice plants in a submerged paddy field and relationships to planting patterns. Field Crops Res. 87:43-58. doi:10.1016/j.fcr.2003.09.004

Shahid, M.Q., Y.J. Li, M.F. Saleem, M. Naeem, C.M. Wei, and X.D. Liu. 2013. Yield and yield components in autotetraploid and diploid rice genotypes (indica and japonica) sown in early and late seasons. Aust. J. Crop Sci. 7:632-641.

She, K.C., H. Kusano, M. Yaeshima, T. Sasaki, H. Satoh, and H. Shimada. 2010. Reduced rice grain production under high-temperature stress closely correlates with ATP shortage during seed development. Plant Biotechnol. 27:67-73. doi:10.5511/plantbiotechnology.27.67

Soto, F., y N. Hernández. 2012. Influencia de tres fechas de siembra en el crecimiento y rendimiento de especies de cereales cultivadas en condiciones tropicales. Parte II. Cultivo del sorgo (Sorghum bicolor L. Moench var. Isiap Dorado). Cultivos Trop. 33:50-55.

Soto, F., R. Plana, y N. Hernández. 2009. Influencia de la temperatura en la duración de las fases fenológicas del trigo harinero (Triticum aestivuns sp.). Cultivos Trop. 30:32-36.

Tabata. M., H. Hirabayashi, Y. Takeuchi, I. Ando, Y. Lida, and R. Ohsawa. 2007. Mapping of quantitative trait loci for the occurrence of white-back kernels associated with high temperatures during ripening period of rice (Oryza sativa L.) Breed. Sci. 57:47-52. doi:10.1270/jsbbs.57.47

Takai, T., Y. Fukuta, T. Shiraiwa, and T. Horie. 2005. Time-related mapping of quantitative trait loci controlling grain-filling in rice (Oryza sativa L.). J. Exp. Bot. 56:2107-2118. doi:10.1093/jxb/eri209

Tao, F., and Z. Zhang. 2013. Climate change, high-temperature stress, rice productivity, and water use in eastern china: A new super ensemble-based probabilistic projection. J. Appl. Meteorol. Climatol. 52:531-552. doi:10.1175/JAMC-D-12-0100.1

Torres, W. 1989. Análisis del crecimiento de las plantas. Instituto Nacional de Ciencias Agrícolas, San José de las Lajas, CUB.

Xiao, G., Q. Zhang, Y. Yao, S. Yang, R. Wang, Y. Xiong, and Z. Sunl. 2007. Effects of temperature increase on water use and crop yields in a pea-spring wheat-potato rotation. Agric. Water Manag. 91:86-91.

Yamagata, H. 1999. Analysis of morphological factors. In: Food and Agriculture Policy Research Center, editor, Science of plant genetics. Food and Agriculture Policy Research Center, Tokyo, JPN. p.227-285.

Yang, J., and J. Zhang. 2010. Grain-filling problem in super rice. J. Exp. Bot. 61:1-5. doi:10.1093/jxb/erp348

Yang, J., and J. Zhang. 2006. Grain filling of cereals under soil drying. New Phytol. 169:223-236. doi:10.1111/j.14698137.2005.01597.x

Yang, J.C., J.H. Zhang, Z.Q. Wang, and Q.S. Zhu. 2001. Water deficit-induced senescence and its relationship to the remobilization of pre-stored carbon in wheat during grain filling. Agron. J. 93:196-206. doi:10.2134/agronj2001.931196x

Zakaria, S., T. Matsuda, S. Tajima, and Y. Nitta. 2002. Effect of high temperature at ripening stage on reserve accumulation in seed in some rice cultivars. Plant Prod. Sci. 5:160-168. doi:10.1626/pps.5.160

Zhang, H., H. Li, L. Yuan, Z. Wang, J. Yang, and J. Zhang. 2011. Post-antesis alternate wetting and moderate soil drying enhances activities of key enzymes in sucrose-to-starch conversion in inferior spikelets of rice. J. Exp. Bot. 63:215-227. doi:10.1093/jxb/err263

Zhang, Y., Q. Tang, S. Oeng, Y. Zou, S. Chen, W. Shi, J. Qin, and M.R. Laza. 2013. Effects of night temperature on yield and agronomic traits of irrigated rice under field chamber system condition. Aust. J. Crop Sci. 7:7-13. doi:10.1093/jxb/err263

Zhu, L., F. Shah, L. Nie, K. Cui, T. Shah, W. Wu, Y. Chen, C. Chen, K. Wang, Q. Wang, Y. Lian, and J. Huang. 2013. Efficacy of sowing date adjustment as a management strategy to cope with rice (Oryza sativa L.) seed quality deterioration due to elevated temperature. Aust. J. Crop Sci. 7:543-549. 